\title{
Rock Mass Characterization using Rock Mass Rating and Encountered Geological Problems in TRT's Component of Tehri Pumped Storage Plant, Uttarakhand, India
}

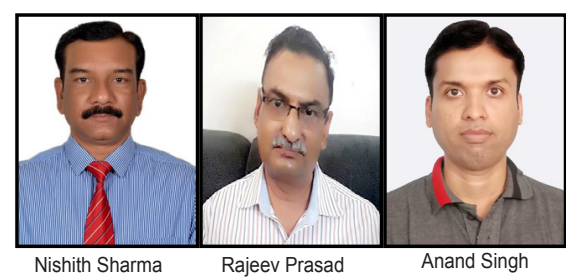

Nishith Sharma, Rajeev Prasad and Anand Singh

Abstract: As an integral part of Tehri Hydro Power Complex (HPC) located in the state of Uttarakhand in Northern India; an underground 4X250 MW Tehri Pump Storage Plant (PSP) parallel and close to the existing $1000 \mathrm{MW}$ Tehri Hydro Power Plant (HPP). Tehri PSP is located on the left bank of Bhagirathi River in the district of Tehri about $1.5 \mathrm{~km}$ downstream of its confluence with River Bhilangana. The major project components are machine hall, upstream surge shafts, Butterfly valve chamber (BVC), Penstock assembly chambers (PAC), downstream Surge Shafts, a pair of Tail Race Tunnels (TRTs) and outlet structures are in construction stage. During underground excavation, one of the important aspects for a speedy and safe excavation is to characterize rock mass for its stand up time. Case history of Himalayan tunnel reveals that Barton's \& Bieniawski's classification system provide better assessment of the rock mass behavior. In TRTs of Tehri PSP, Rock Mass Rating (RMR) classifications were implemented during excavation and based on their ratings, rock mass was supported. Construction stage geotechnical assessments were made, and suitable remedies were adopted for all the components of the project after geological traverses, detailed geological mapping, drift logs and logging of cores was done. This paper deals with rock mass characterization of underground structures specially in TRT's using RMR classification and encountered geological problems during excavation.

Keywords: Weak rock, shear zones, chimney formation, rock supports, Tehri, India

\section{Introduction}

$\mathrm{T}$ unneling is an important component of any hydroelectric project located in the Himalayas. Due to the rugged and uncongenial nature of the terrain, it is usually not possible to carry out thorough investigations along the tunnel alignments. The use of rock mass classification systems for the underground excavation under such condition provides better idea for their design. The 2400 MW Tehri Hydro Power Complex comprises of Tehri Dam and 1000 MW Tehri Hydro Power Project (HPP) Stage-I, 400 MW Koteshwar HEP and 1000 MW Tehri Pumped Storage Project (PSP). Tehri Pumped Storage Project comprising of four reversible turbines of $250 \mathrm{MW}$ each, involves construction of underground caverns, chambers, TRTs and shafts on the left bank of River Bhagirathi.

The present case study is of a typical Himalayan tunnel, where application of rock mass classification systems formed a major part of geotechnical studies conducted for the evaluation of tunneling conditions. Tehri PSP is implemented by two TRTs which is known as TRT- 3 and TRT-4 having length of $1078 \mathrm{~km}$ and 1187 $\mathrm{m}$ respectively. These tunnels are constructed in a single litho unit of meta-sedimentary rock which is Phyllites. In order to facilitate the excavation of TRTs, one single Adit (EA-7) was provided at chainage $148.5 \mathrm{~m}$ and 214 $m$ in TRT- 3 and TRT- 4 respectively. RMR classification was used for identifying the rock class, and based on rock mass rating, support was provided. The general layout plan along with encountered geology of TRTs of Tehri PSP is shown below in Figure 1.

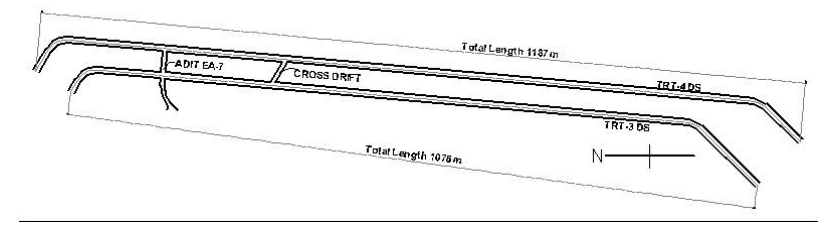

Figure1: Showing Layout Plan of TRTs.

\section{Regional Geological Setting}

Project site is within the Lesser Himalaya which lies tectonically between the Main Central Thrust and the Main Boundary Thrust. The former separates meta sedimentary sequence of Lesser Himalaya to the north from crystalline rocks of Higher Himalaya and latter disjoins the Lesser Himalayan sequence from molasses sediments of Frontal Fold Belt (FFB), in the south. Phyllites of Chandpur formation of Jaunsar group, and quartzites and metabasics of Garhwal group are exposed along the project. Most prominent tectonic features; Srinagar Thrust lies $5 \mathrm{~km}$ north of the project and it crosses Bhagirathi River at Nalupani, and Bhilangana River at Gadolia. Rock units are part of the low grade metamorphic rock that have been thrusted, folded and deformed. There are two main tectono-stratigraphic units: the Krol Super Group and the Gharwal Group. This former Super Group is subdivided into the Jaunsar Group and Krol Group. Jaunsar Group is found at the Tehri site and includes quartzites and phyllites in varying proportions that have undergone various phases of deformation leading to development of numerous tectonic dislocations, sheared zones, seams and joints of different scales 
and categories. Type of lithology categorized in the Tehri site have been classified during the dam and HPP design and construction by Geological Survey of India, and same has been adopted for the PSP. The nomenclature has been based on variable proportions, and quality of quartzite and Phyllite include: PQM Phyllitic Quartzite Massive; PQT - Phyllitic Quartzite, Thinly Bedded; QP - Quartzitic Phyllite; SP - Sheared/ Shattered Phyllite.

Rock Mass Characterization in Tail Race Tunnel The working faces of the tailrace tunnels are accessed by the Exploratory Adit (EA-7) having $10.90 \mathrm{~m}$ diameter of tunnels, excavated through heading and benching methods. The excavated horse shoe shaped TRTs have $850 \mathrm{~mm}$ thick reinforced concrete lining in circular shape. The excavation traversed through diverse geological conditions and it was found that the rock mass was discontinuous mainly due to joints, shear planes, bedding planes, foliations, puckered/warped zone, and at places due to presence of shearing/ minor faults.

The quartzite is mid- to dark grey mainly composed of quartz but has thin phyllitic bands through it that are reported to contain mostly the fine mica (sericite) and chlorite. The phyllite, where described as SP, has a high proportion of fine quartz and may be better described as siliceous phyllite; but the term "quartzitic phyllite" has been adopted. There are also gradations or mixtures between these main groups such as PQM/PQT, or PQT with SP. Additionally the rock quality is grouped according to physical and mechanical competency and anisotropic behavior in relation to their disposition. All these rock variants were encountered in underground excavation in the form of alternative bands with varying extent.

\section{Phyllitic Quartzites Massive (PQM)}

PQM represents the massive and blocky Phyllitic quartzites rock, grey, dark grey, brownish grey, greenish grey, greyish green in color. They are more arenaceous and occasionally micaceous in composition and are coarser in grain size. Foliations which are the dominant joint set are moderately spaced with medium to high persistence. Sedimentary structures like primary bedding, current bedding and ripple marks are better preserved in these rocks. The bedding surface is rough, undulating with sound and un-weathered to slightly weathered in nature. These rocks are composed mainly of Quartz (60-80\%) and feldspar (10-15\%), sizes varying from $0.05 \mathrm{~mm}$ to $0.15 \mathrm{~mm}$.

\section{Phyllitic Quartzites Thinly Foliated (PQT)}

PQT represents the thinly foliated Phyllitic quartzites rock, grey, dark grey, brownish grey, greenish grey, greyish green in color. They are more arenaceous and occasionally micaceous in composition and are coarser in grain size. Foliations which are the dominant joint set are very closely to closely spaced with medium to high persistence. The bedding surface is rough, undulating with un-weathered to slightly weathered in nature. These rocks are composed mainly of Quartz (60-80\%) and feldspar (10-15\%), sizes varying from $0.05 \mathrm{~mm}$ to $0.15 \mathrm{~mm}$

\section{Quartzitic Phyllites (QP)}

QP represents more argillaceous, fine grained and dark colored. Foliations are well developed with close to moderate spacing. Minor folds and puckers are better preserved in QP rocks. Silicification along joints planes is very common. This rock is composed of Quartz (60$60 \%)$, and feldspar (5-15\%), represented by isometric grains of $0.03 \mathrm{~mm}$ to $0.05 \mathrm{~mm}$ size.

\section{Sheared Phyllites (SP)}

Sheared Phyllites are tectonied variants of PQM, PQT and QP rocks, developed mostly in the vicinity of major shears, and form weak zones characterized by mylonites, phyllonites, - highly fissured rock, crumpling and intensive Schistosity. The strength of rock represents Ro to R1 grade, and degree of weathering as completely weathered to highly weathered. Sheared Phyllites are predominantly argillaceous in composition. The encountered geology during tunneling of TRT is marked in the following L-section along TRT.

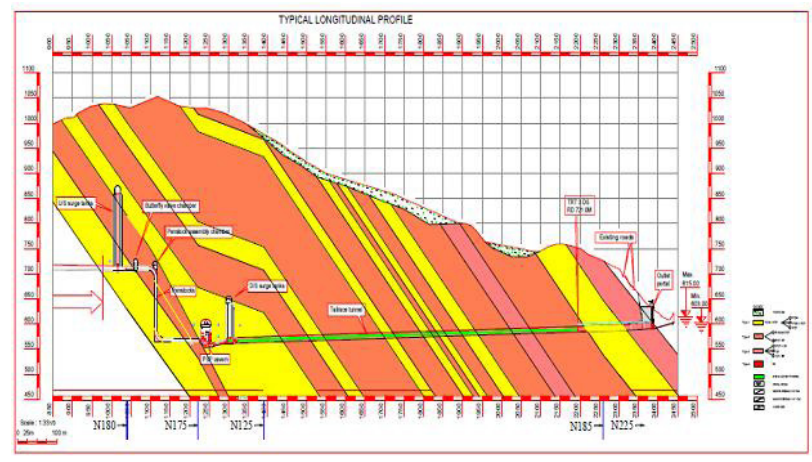

Figure 2: L section of encountered geology during tunneling of TRTs of Tehri PSP.

The rock formations at the project site are Phyllites of Chandpur series. Phyllites, in general, are banded in appearance; the bands are constituted of variable proportions of argillaceous and arenaceous material. The Phyllites have found to be traversed by numerous major and minor shear zones and weak planes. The TRTs are crossing through different rock variant called $\mathrm{PQM}+\mathrm{PQT}, \mathrm{PQT}+\mathrm{SP}, \mathrm{QP}+\mathrm{SP}$ and SP. Four sets of discontinuities were frequented, and their discontinuity characteristics are given below: 


\begin{tabular}{|c|c|c|c|c|c|c|}
\hline $\begin{array}{c}\text { S e t } \\
\text { No. }\end{array}$ & Feature & $\begin{array}{c}\text { A v e ra g e } \\
\text { Orientation }\end{array}$ & Persistence & Aperture & Spacing & Condition \\
\hline $\mathrm{J} 1$ & Bedding & $\mathrm{N} 210^{\circ} / 45^{\circ}$ & 3 to $10 \mathrm{~m}$ & Tight to $8 \mathrm{~mm}$ & 3 to $20 \mathrm{~cm}$ & Smooth Undulating \\
\hline $\mathrm{J} 2$ & Foliation & $\mathrm{N} 150^{\circ} / 40^{\circ}$ & 1 to $5 \mathrm{~m}$ & Tight to $5 \mathrm{~mm}$ & 10 to $30 \mathrm{~cm}$ & Smooth Planner \\
\hline $\mathrm{J} 3$ & Joints & $\mathrm{N} 025^{\circ} / 60^{\circ}$ & 1 to $5 \mathrm{~m}$ & Tight & 30 to $60 \mathrm{~cm}$ & $\begin{array}{c}\text { Slightly rough/ } \\
\text { Planner }\end{array}$ \\
\hline $\mathrm{J} 4$ & Joints & $\mathrm{N} 285^{\circ} / 70^{\circ}$ & 1 to $3 \mathrm{~m}$ & Tight & 50 to $90 \mathrm{~cm}$ & $\begin{array}{c}\text { Slightly rough/ } \\
\text { Planner }\end{array}$ \\
\hline
\end{tabular}

folding/ warping within rock variants, no linear persistence of litho units were found at site and is confirmed with excavation of opening. Some of the engineering properties of the rock samples are tabulated

Table 1: Showing Characteristics of Joint Sets Observed in TRTs.

All the rock units along the TRTs have been classified using RMR system proposed by Bieniawski, 1989. Different rock units along the TRTs that are classified using RMR system, have poor to fair rock quality. Occurrences of shear zones and weak Phyllite bands in the rock mass almost always was associated with loose falls and cavity formations. In such reaches, class IV and V kind of conditions had to be negotiated. The percentages of classes as per Beiniawski's Rock Mass Rating (RMR) system evaluated in the TRTs are shown in the following graph (Figure 3).

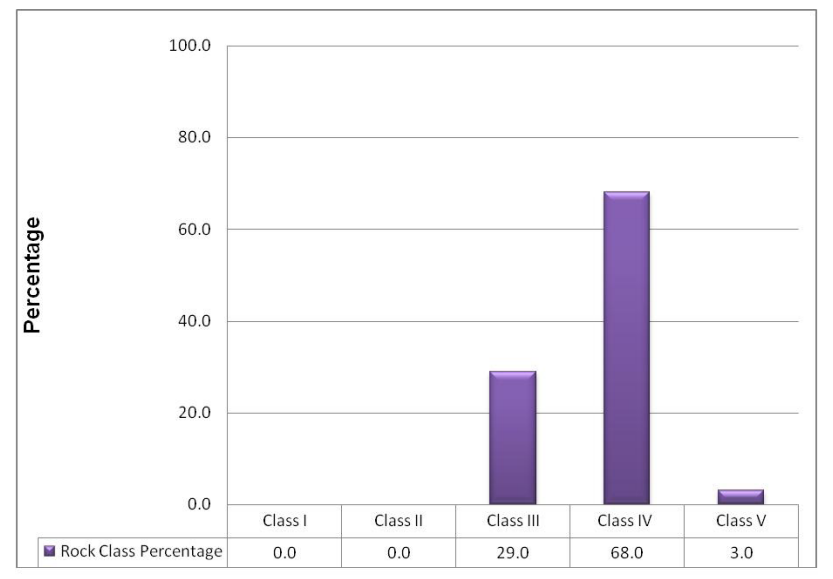

Figure 3: Percentage of rock class encountered during excavation of TRT-3 and TRT-4.

\section{Engineering Properties of Rock Mass}

In-situ stress in Himalayan region varies from place to place. A major uncertainty lies in forecasting the magnitude of the stresses in different sections of tunnel alignment, due to the rock cover and closer valley side associated with poly phase deformations in Himalayan region. Hence, in-situ stresses are measured by means of hydraulic fracturing or flat jack test at different locations. The phenomenon of squeezing, which cause an inward movement of the tunnel periphery due to dilation or distressing, needs to be accounted to ensure safety of tunnel support (Bieniawski, 1979). To depict the physico-mechanical properties of rock mass along the various project components, in-situ rock mechanics testing has been conducted at site. A variation in tested value of same drill hole samples indicated complex geology of PSP. Due to this complex geology and local

\begin{tabular}{|c|c|c|}
\hline Parameters & Ground Type & $\begin{array}{c}\text { As per test results/ } \\
\text { site }\end{array}$ \\
\hline \multirow{3}{*}{$\begin{array}{l}\text { U n i a x i a l } \\
\text { Compressive } \\
\text { Strength (UCS- } \\
\text { MPa) }\end{array}$} & PQT & $68.66 / 22$ \\
\hline & PQT with SP & $51.99 / 29 / 26$ \\
\hline & SP & - \\
\hline \multirow{3}{*}{$\begin{array}{l}\text { D e f o r m a t i o } n \\
\text { Modulus } \\
\text { (Ed-GPa) }\end{array}$} & PQT & $5.4 / 4.0$ \\
\hline & PQT with SP & $4.7 / 4.4 / 3.1$ \\
\hline & SP & \\
\hline \multirow{3}{*}{$\begin{array}{l}\text { G e o l o g i c a I } \\
\text { Strength Index } \\
\text { (GSI) }\end{array}$} & PQT & $45 / 38$ \\
\hline & PQT with SP & $37 / 33$ \\
\hline & SP & $25 / 20$ \\
\hline \multirow{3}{*}{$\begin{array}{l}\text { Rock shear } \\
\text { parameters } \\
(\text { C -MPa \& } \\
\text { ( -degree) }\end{array}$} & PQT & $\begin{array}{c}3.0(\mathrm{C}) \\
24.88(\varphi)\end{array}$ \\
\hline & PQT with SP & $\begin{array}{c}1.53 / 1.36(C) \\
38.40 / 33.95 / 20.33(\varphi)\end{array}$ \\
\hline & SP & - \\
\hline $\begin{array}{l}\text { Joint } r \text { shear } \\
\text { parameters } \quad \text { (C } \\
\text {-MPa \& }(\text {-degree) }\end{array}$ & $\mathrm{PQT}$ & $\begin{array}{c}0.91 / 0.71(C) \\
28.69 / 29.05(\varphi)\end{array}$ \\
\hline
\end{tabular}

Table 2: Engineering properties of rock mass encountered in TRTs.

\section{Problems Encountered During Tunneling}

The tunneling in the soft rocks of Himalayas with adverse geological and hydrological condition poses a number of problems, such as, squeezing condition, cavity or chimney formation and roof collapse etc. The geological problems were mainly encountered due to shear zones, high rock stresses and water ingress. The main problems encountered during tunneling are mentioned below.

\section{Encounter of Shear Zones}

A number of shear zones were encountered and negotiated during excavation of TRTs. The thickness of these shear zones varied from $5 \mathrm{~mm}$ to $50 \mathrm{~cm}$. The shear zones were comprised of clayey and crushed rock infilling matrix. Sometimes big cavities are formed due to the intersection of shear zones. From the 3-D geological mapping of the TRTs, it is observed that if $\mathrm{PQM}$ with PQT is encountered during tunneling which is hard \& massive in comparison to PQT with SP and SP alone falls in class III \& RMR value ranges between 
41 to 50. If PQT with SP is encountered, it falls in class IV and RMR value ranging from 32 to 40 . If only SP is encountered during tunneling, it falls in class $\mathrm{V}$ and RMR value ranges between 17-20. Geological face logs of different litho units correlated with rock classes during excavation of TRTs is shown in Fig 4 below.

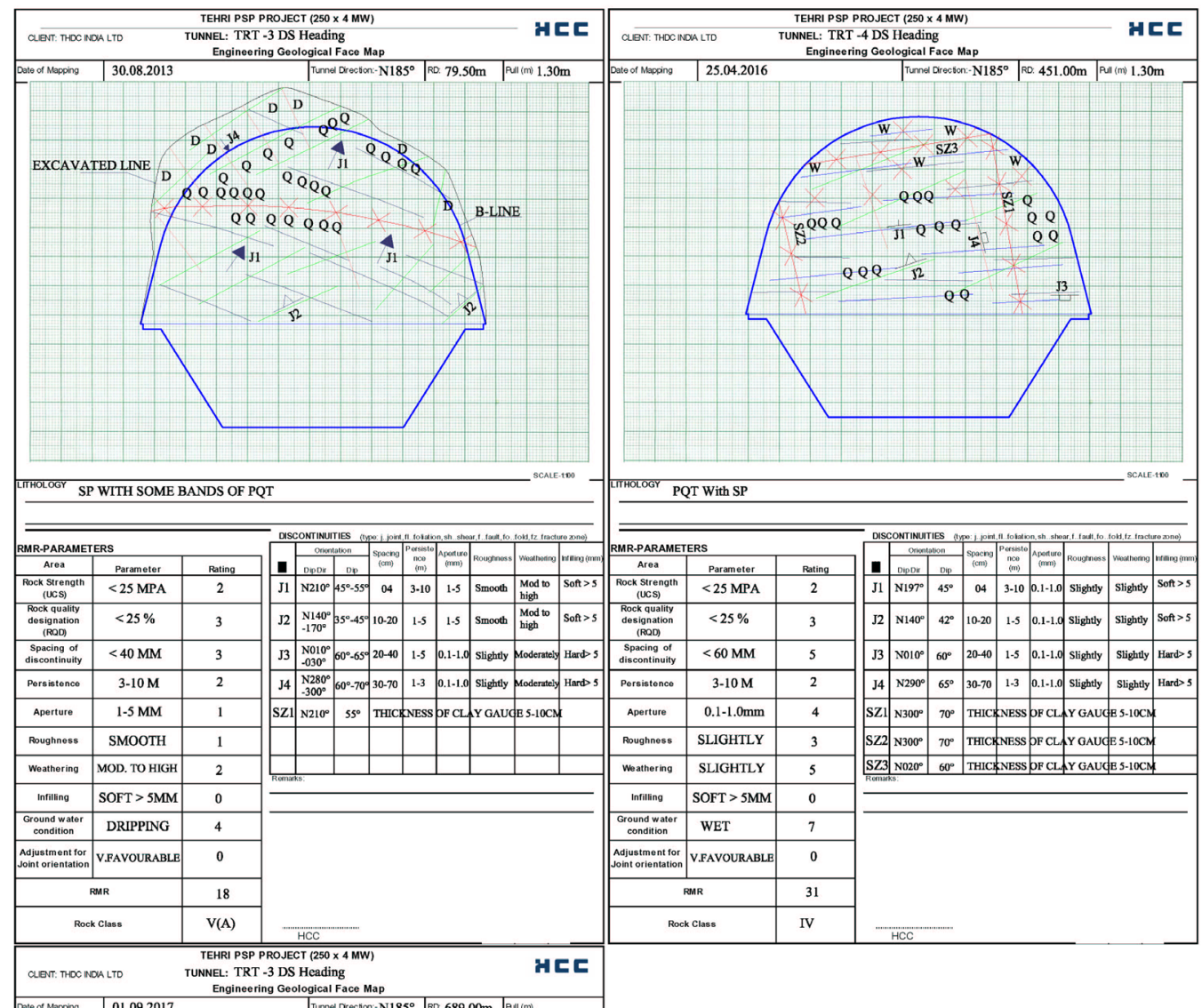

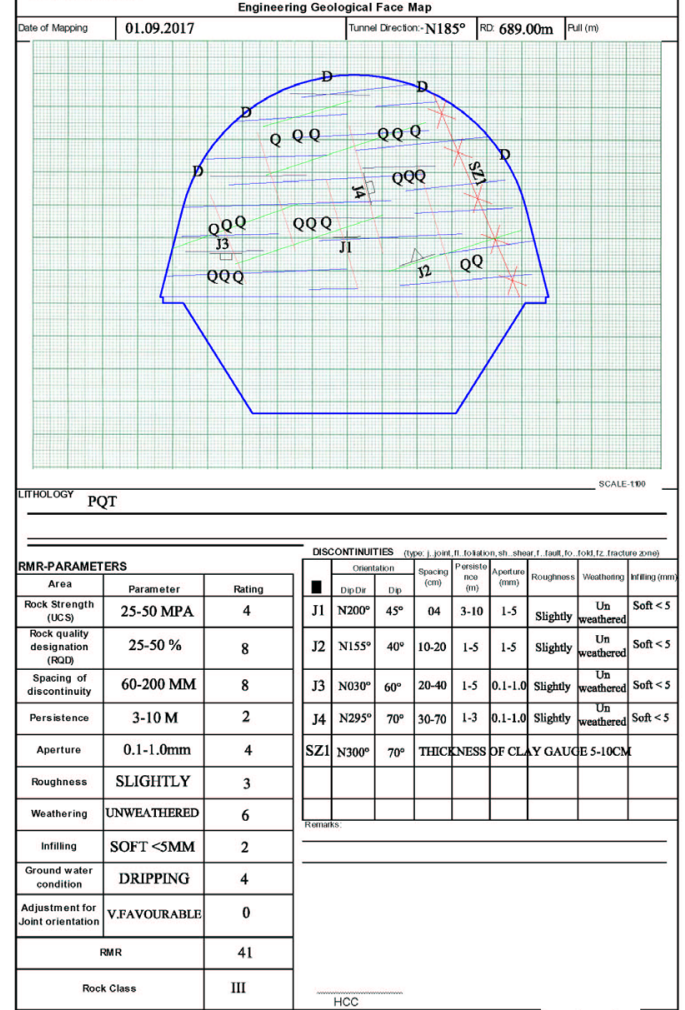

Figure 4. Geological face logs in different litho units at different locations in both TRTs 
Many shear zones are encountered during excavation of TRTs which include minor, major and mega shear zones. Details of encountered mega shear zones are tabulated below.

\section{Seepage conditions}

Groundwater conditions along both TRTs are normal. The excavated reaches of TRT- 3 and 4 present essentially dry conditions with some wet and damp areas. Dripping has also been found at localized zones. No flowing conditions have been reported from PSP excavations.

\section{Remedial Measures for Cavity Zones}

Cavities are mainly formed due to presence of shear zones along with seepage condition. Shear seams are categorized in three types based on thickness of filling materials, such as clay gauge. Filling material less than $5 \mathrm{~cm}$ are termed as minor shear, whereas 5-10 $\mathrm{cm}$ and $>10 \mathrm{~cm}$ are termed as major and mega shears, respectively. Most of the encountered shear seams are major shears. A number of minor to major shear zones (clay filled) have also been encountered from the $3 \mathrm{D}$ geological logs of TRTs.

\begin{tabular}{|c|c|c|c|c|}
\hline S.: & $\begin{array}{l}\text { Shear Zone } \\
\text { Chainage (m) }\end{array}$ & Orientation & Thickness & Supports Provided \\
\hline 1 & $187-194 m$ & $\mathrm{~N} 095^{\circ} / 45^{0}$ & $\begin{array}{l}\text { Bedding shear, clay } \\
\text { infilling, } 10-15 \quad \mathrm{~cm} \\
\text { thick }\end{array}$ & $\begin{array}{l}\text { Steel Rib support with } \\
\text { backfill concrete }\end{array}$ \\
\hline 2 & $173-177 m$ & $\mathrm{~N} 185^{\circ} / 45^{\circ}$ & $\begin{array}{l}\text { Foliation shear, clay } \\
\text { gouge infilling, } 20 \text { to } \\
25 \mathrm{~cm} \text { thick }\end{array}$ & $\begin{array}{l}\text { Steel Rib support with } \\
\text { backfill concrete }\end{array}$ \\
\hline 3 & $151-155 m$ & $\mathrm{~N} 150^{\circ} / 45^{\circ}$ & $\begin{array}{l}\text { Bedding shear, clay } \\
\text { infilling, } 10-15 \quad \mathrm{~cm} \\
\text { thick }\end{array}$ & $\begin{array}{l}\text { Steel Rib support with } \\
\text { backfill concrete }\end{array}$ \\
\hline 4 & $123-135 m$ & $\mathrm{~N} 025^{\circ} / 60^{\circ}$ & $\begin{array}{c}\text { Gouge infilling, } 35- \\
50 \mathrm{~cm} \text { thick }\end{array}$ & $\begin{array}{c}\text { Steel Rib support with } \\
\text { backfill concrete }\end{array}$ \\
\hline 5 & $113-117 m$ & $\mathrm{~N} 190^{\circ} / 50^{\circ}$ & $\begin{array}{l}\text { Foliation shear, } \\
\text { gouge infilling, } 30 \text { to } \\
35 \mathrm{~cm} \text { thick }\end{array}$ & $\begin{array}{l}\text { Steel Rib support with } \\
\text { backfill concrete }\end{array}$ \\
\hline 6 & $102-117 m$ & $\mathrm{~N} 140^{\circ} / 45^{\circ}$ & $\begin{array}{l}\text { Bedding shear, clay } \\
\text { infilling, } 30-35 \quad \mathrm{~cm} \\
\text { thick }\end{array}$ & $\begin{array}{l}\text { Steel Rib support with } \\
\text { backfill concrete }\end{array}$ \\
\hline 7 & $226-254 m$ & $\begin{array}{c}N 015^{\circ} / 65^{\circ}- \\
75^{\circ}\end{array}$ & $\begin{array}{l}\text { Sub vertical; } 25-35 \\
\mathrm{~cm} \text { thick }\end{array}$ & $\begin{array}{l}\text { Steel Rib support with } \\
\text { backfill concrete }\end{array}$ \\
\hline 8 & $288-316 m$ & $\mathrm{~N} 090^{\circ} / 50^{\circ}$ & $\begin{array}{l}\text { Bedding shear, clay } \\
\text { infilling, } 10-150 \mathrm{~cm} \\
\text { thick }\end{array}$ & $\begin{array}{l}\text { Steel Rib support with } \\
\text { backfill concrete }\end{array}$ \\
\hline 9 & $472-484 m$ & $\mathrm{~N} 210^{\circ} / 65^{0}$ & $\begin{array}{l}\text { Foliation shear, } \\
\text { gouge infilling, } 40 \text { to } \\
50 \mathrm{~cm} \text { thick }\end{array}$ & $\begin{array}{l}\text { Steel Rib support with } \\
\text { backfill concrete }\end{array}$ \\
\hline 10 & $534-545 m$ & $\mathrm{~N} 210^{\circ} / 65^{0}$ & $\begin{array}{l}\text { Foliation shear, } \\
\text { gouge infilling, } 15 \text { to } \\
20 \mathrm{~cm} \text { thick }\end{array}$ & $\begin{array}{l}\text { Steel Rib support with } \\
\text { backfill concrete }\end{array}$ \\
\hline 11 & $550-554 m$ & $\mathrm{~N} 030^{\circ} / 50^{\circ}$ & $\begin{array}{c}\text { Clay infilling; } 20-30 \\
\text { cm thick }\end{array}$ & $\begin{array}{l}\text { Steel Rib support with } \\
\text { backfill concrete }\end{array}$ \\
\hline 12 & $654-701 m$ & $\mathrm{~N} 300^{\circ} / 65^{\circ}$ & $\begin{array}{l}\text { Sub vertical; } 30 \mathrm{~cm} \\
\text { thick }\end{array}$ & $\begin{array}{l}\text { Steel Rib support with } \\
\text { backfill concrete }\end{array}$ \\
\hline 13 & $800-814 m$ & $\mathrm{~N} 300^{\circ} / 70^{\circ}$ & $\begin{array}{l}\text { Sub vertical; clay } \\
\text { infilling; } 30-40 \text { cm } \\
\text { thick }\end{array}$ & $\begin{array}{l}\text { Steel Rib support with } \\
\text { backfill concrete }\end{array}$ \\
\hline 14 & $108-144 m$ & $\mathrm{~N} 110^{\circ} / 70^{\circ}$ & $\begin{array}{l}\text { Sub vertical; clay } \\
\text { infilling; } 20-25 \mathrm{~cm} \\
\text { thick }\end{array}$ & $\begin{array}{l}\text { Steel Rib support with } \\
\text { backfill concrete }\end{array}$ \\
\hline 15 & $387-389 m$ & $\mathrm{~N} 030^{\circ} / 65^{\circ}$ & $\begin{array}{l}\text { Sub vertical; } \\
\text { infilling; } 20-25 \text { clay } \\
\text { thick }\end{array}$ & $\begin{array}{l}\text { Steel Rib support with } \\
\text { backfill concrete }\end{array}$ \\
\hline 16 & $415-418 m$ & $\mathrm{~N} 020^{\circ} / 30^{\circ}$ & $\begin{array}{c}\text { Clay infilling; } 25-35 \\
\mathrm{~cm} \text { thick }\end{array}$ & $\begin{array}{l}\text { Steel Rib support with } \\
\text { backfill concrete }\end{array}$ \\
\hline 17 & $565-587 m$ & $\mathrm{~N} 010^{\circ} / 68^{0}$ & $\begin{array}{l}\text { Sub vertical; clay } \\
\text { infilling; } 20-30 \mathrm{~cm} \\
\text { thick }\end{array}$ & $\begin{array}{l}\text { Steel Rib support with } \\
\text { backfill concrete }\end{array}$ \\
\hline 18 & $671-681 m$ & $\mathrm{~N} 190^{\circ} / 48^{\circ}$ & $\begin{array}{l}\text { Foliation shear, clay } \\
\text { infilling, } 40 \text { to } 50 \mathrm{~cm} \\
\text { thick }\end{array}$ & $\begin{array}{l}\text { Steel Rib support with } \\
\text { backfill concrete }\end{array}$ \\
\hline
\end{tabular}

Table 3. Details of encountered mega shear zones 

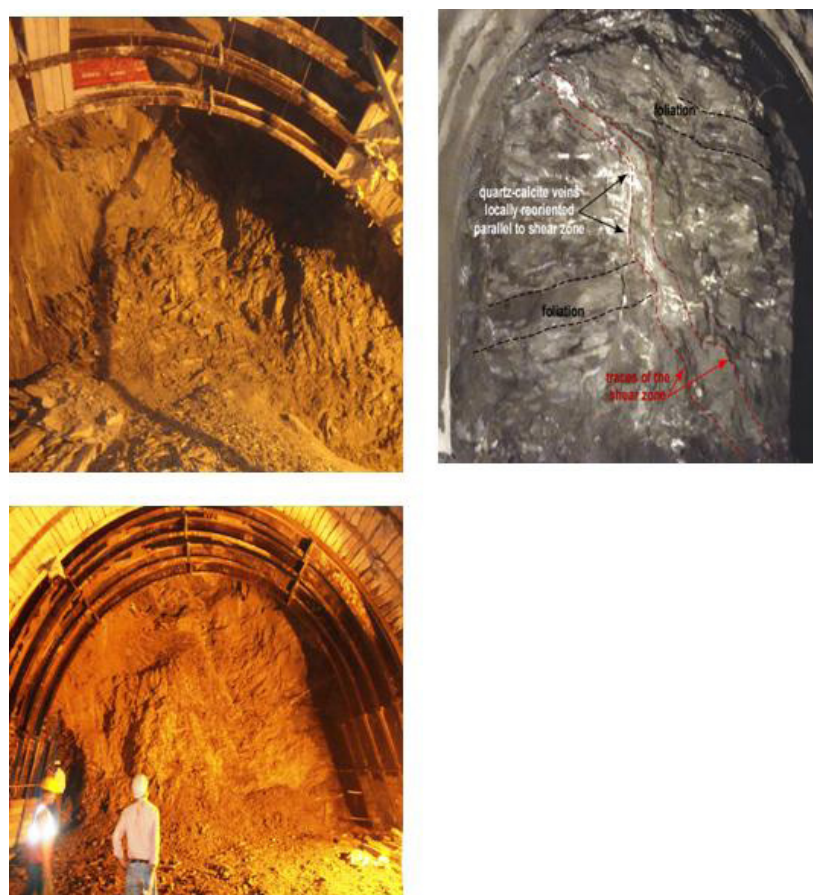

Figure 5. Showing shattered rock mass due to presence of many shear zones and damp to dripping water condition just after excavation in TRTs.

\begin{tabular}{|c|c|c|c|c|}
\hline $\begin{array}{l}\text { S } \\
\text { No. }\end{array}$ & Rock Support & TRT-3 & TRT-4 & $\begin{array}{l}\text { T o t a I } \\
\text { Support }\end{array}$ \\
\hline 1 & $\begin{array}{l}\text { Rock Bolts } \\
\text { (25mm dia.) }\end{array}$ & 33883 m & $32257 \mathrm{~m}$ & \multirow[b]{2}{*}{$96464 \mathrm{~m}$} \\
\hline 2 & $\begin{array}{l}\text { Rock Bolts } \\
(32 \mathrm{~mm} \text { dia.) }\end{array}$ & 11694 m & $18630 \mathrm{~m}$ & \\
\hline 3 & Shotcrete & $1600 \mathrm{~m}^{3}$ & $1623 \mathrm{~m}^{3}$ & $3223 \mathrm{~m}^{3}$ \\
\hline 4 & Ribs & 512.3 MT & $\begin{array}{l}728.7 \\
\text { MT }\end{array}$ & $1241 \mathrm{MT}$ \\
\hline 5 & $\begin{array}{l}\text { B a c k f i I I } \\
\text { Concrete }\end{array}$ & $6642 \mathrm{~m}^{3}$ & $\begin{array}{l}10375 \\
\mathrm{~m}^{3}\end{array}$ & $17017 \mathrm{~m}^{3}$ \\
\hline
\end{tabular}

Table 4. shows the details of all rock support installed in both TRTs to protect the wedge failure, plane failure, and chimney/ cavity formation.

\section{Construction Stage Instrumentation}

The geotechnical instrumentation plays a vital role in evaluating the structural performance of an underground structure. The natural ground or rock mass tends to deform and de-stress when subjected to excavations, foundation and other loadings etc. Activities like squeezing, swelling and creeping, depending upon the mechanical characteristics of the material, are also responsible for the disturbances inside the underground rock mass.

The monitoring instruments installed till date, at various locations in the TRTs, are mentioned below.

\section{Bi-Reflex Targets}

Bi-Reflex Targets consists of reflector plate mounted on a robust frame. The target has reflectors on both sides and is mounted on a universal joint such that it can be oriented in any direction as required. The target has a cross mark to allow precise targeting. The deformation of different rocks exposed at tunnel periphery has been monitored at one and five places (targets $\mathrm{T} 1$ and $\mathrm{T} 1$ to $\mathrm{T}_{5}$ ) by fixing bi-reflex targets as shown in figure, according to encountered rock class. A maximum value of movement with respect to initial in TRT- 3 and TRT4 was observed as $4.5 \mathrm{~mm}$ and $5.4 \mathrm{~mm}$ at RD $146 \mathrm{~m}$ \& $724 \mathrm{~m}$ respectively. Movement observed in other RD's are negligible.
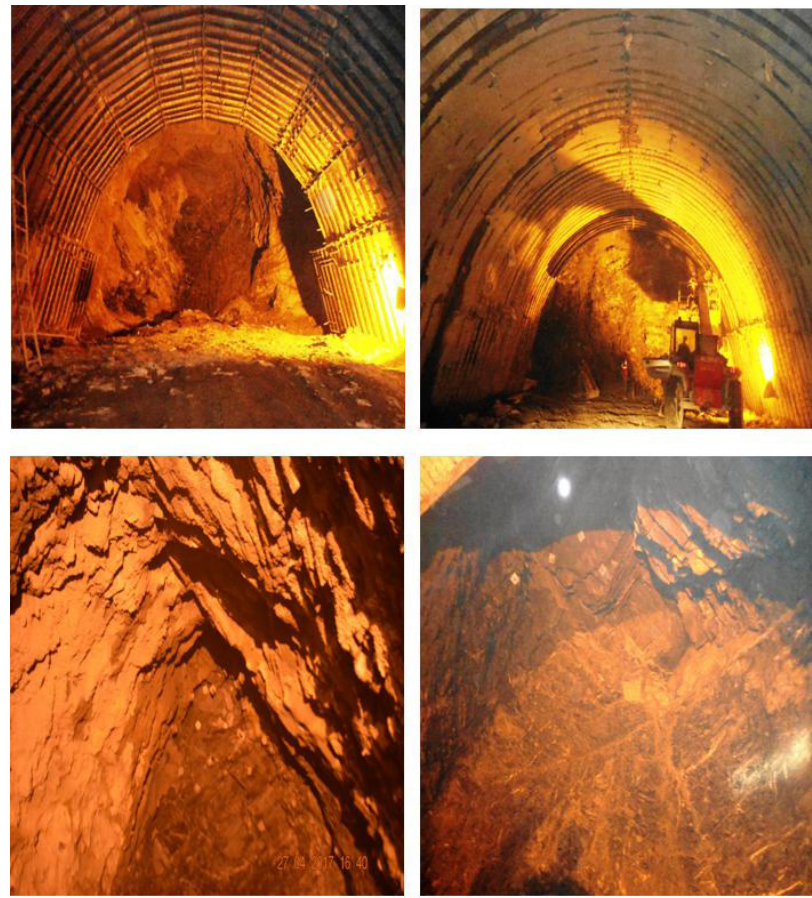

Figure 6: Encountered poor rock condition and their treatment at different locations in both TRTs.

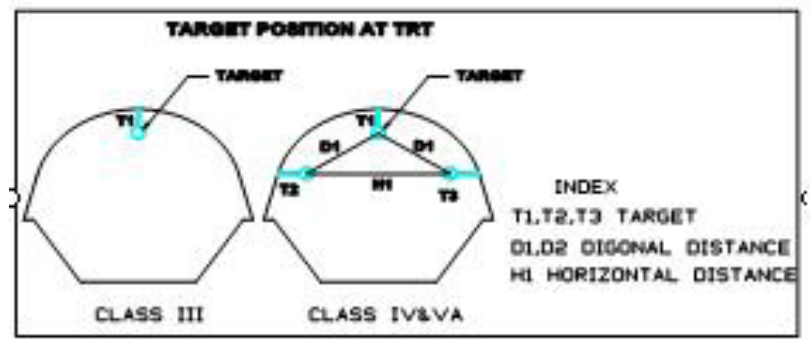

Figure 7: Array of target points at one location in different rock classes to measure tunnel deformation in TRTs.

\section{Conclusion}

In TRTs of Tehri PSP, RMR classification was used to characterize the rock mass and accordingly, rock support was provided to increase the stand-up time. From the geological logging of the TRTs, it is observed that there are mainly 3 types of rock units i.e. PQT, PQT with SP and SP. Encounter of PQT, PQT with SP and SP will fall in class III, IV and V respectively. Construction stage geotechnical assessments were made and suitable remedies were adopted after geological traverses, detailed geological mapping and logging of cores. 
Excavation methodology for critical reaches and recommendation of additional rock support system for treatment of adverse geological condition are very challenging. Moreover, presence of shear seams and soft infilling reduces the overall strength of rock mass.

\section{Acknowledgements}

Authors are thankful to the management of THDC India Ltd. and $\mathrm{M} / \mathrm{s}$. Hindustan Construction Co. Ltd. for providing necessary support to carry out the work. The authors are also very thankful to Dr. R. Anbalagan, Professor, Department of Earth Science, IIT Roorkee for his overall guidance to represent the paper.

Nishith Sharma, Project Construction Head, Hindustan Construction Company Ltd.: received B.E (Civil), University of Mysore 1993. PGDCM from NICMAR. And over 23 years of experience in field of large infrastructure projects in India.

E-mail : sharma.nishith@rediffmail.com

Rajeev Prasad, Chief Geologist, Hindustan Construction Company Ltd.: Received M.Tech in Applied Geology from IIT Roorkee in 1989 and has over 28 years of multidisciplinary experience in managing large construction projects at various positions and locations in India.

Corresponding E-mail : rpindia@hotmail.com
Anand Singh, Sr. Geologist, Hindustan Construction Company Ltd.: received Post Graduate degree in Geology from University of Lucknow in 2007 and has over 11 years of experience in underground works \& slope stability analysis of major infrastructure projects in India.

E-mail : anandsingh1oo@gmail.com

\section{References}

Bieniawski, Z.T. (1973). Engineering classification of jointed rock masses. Trans. S.Afr. Inst. Civ.Eng.15, 335-344.

Bieniawski, Z.T. (1979). The geomechanics classification rock engineering applications. Proc. 4th Int. Congr. Rock Mech., ISRM, Montreux, 1979, vol.2, 41-48.

Bieniawski, Z.T. 1989. Engineering rock mass classification: Jhon Wiley \& Sons. New York, 272 p.

Detailed Project Report of Tehri PSP, Unpublished report. 